\title{
Methodology of Forming of Economical and Geographical Competence of a Modern Education System
}

\author{
Morozova I. G. \\ Department of Marketing and Economy \\ V.G. Timiryasov Innovation University \\ Kazan, Russia \\ morozovaig@yandex.ru \\ Khayaleeva A.D. \\ Kazan (Volga region) Federal University \\ Kazan, Russia \\ camat185@mail.ru
}

\author{
Abdullin I. I. \\ Department of Financial Accounting and Taxation \\ University of management "TISBI" \\ Kazan, Russia \\ abdoulin@inbox.ru \\ Rocheva O.A. \\ V.G. Timiryasov Innovation University \\ Kazan, Russia \\ rochevaolga@mail.ru
}

\begin{abstract}
The methodology of forming of economical and geographical competence of a modern education system is considered. Implementation of the federal state educational standards (FSES) in the organizations of the secondary (complete) general education caused need of realization of competence approach and became a basis of change of training results of future specialists. The aim of educational institutions is to raise educated enterprising people capable to make rational choice and to make decisions, to bear responsibility for own activity and the social and economic future of the country.
\end{abstract}

Keywords-economy; geography; competence; economical and geographical competence.

\section{INTRODUCTION}

Implementation of the federal state educational standards (FSES) in the organizations of the secondary (complete) general education caused a need of competence approach realization and became a basis of future specialists training results change. The aim of educational institutions is to raise educated enterprising people capable to make rational choice and to make decisions, to bear responsibility for own activity and the social and economic future of the country. In this regard one of the leading ideas of modernization of naturalscience education is forming of economical and geographical competence of the senior.

\section{LITERATURE REVIEW}

Economical and geographical competence is the integrative quality of the personality which is applied for the gaining of economical and geographical knowledge and skills used in daily practical activities in a certain situation for the solution of a certain task. $[1,2,6]$.

\section{RESEARCH METHODOLOGY}

Natural-science disciplines allow to use, fix and deepen knowledge and abilities, to have opportunities of development of thinking and of creative capabilities of the person, which are the basis of future professions. We will consider more details on the example of studying of the subject "Role of the Arctic in the Modern World".

The Arctic is an area on the physical map of the globe, characterized by significant originality. The total area of the Arctic is 27 million $\mathrm{km}^{2}$, if you include in this region the territory on the southern border of the tundra. There is altev cerebrating and its method of calculating the area of the Arctic, which is considered the edge of the Arctic circle. In the case of such a calculation, the total area of the Arctic is 21 million $\mathrm{km}^{2}$. Currently, the status of the Arctic countries have several countries in the world that have territories directly on the coast of the Arctic ocean. These are Canada, USA, Russia, Norway, Denmark. In the modern scientific and organizational-legal understanding, a number of approaches to the definition of the term "Arctic"are distinguished. Taking into account the objectives of the study and the scope of use, various definitions of this concept can be formulated. The category "Arctic" can be used now in such spheres and branches of knowledge as the geological dictionary, the international and public law, the geographical encyclopedia.

Understanding of the term "Arctic", which is most common in encyclopaedias, is as follows: the Arctic is the Northern polar region of the globe, which includes adjacent 
State interest in the Arctic zone is also connected with the areas of Eurasian and North American continents, the Arctic ocean and the Pacific and Atlantic oceans. The word "Arctic" has Greek origin and translated into Russian means "Northern". In General, at the present stage can be considered a well-established understanding of the Arctic Arctic ocean with Islands and seas, the outskirts of North America and Eurasia.

In the Arctic zone are located: the large archipelago of Svalbard, Greenland - the largest island on the globe, many smaller Islands and archipelagos. Russia has several seas within the waters of the Arctic ocean, located in the Eastern hemisphere of the Earth:

- East Siberian sea,

- Kara sea,

- Chukchi sea,

- White sea,

- Barents sea,

- Laptev sea.

The Northern seas of the Western hemisphere, included in the waters of the Arctic ocean, include:

- Baffin Bay,

- Greenland sea,

- The Lincoln Sea,

- Beaufort sea.

In terms of natural and climatic conditions, the Arctic is a unique region of the globe. Glaciers and permafrost are common in this area. The Arctic zone is characterized by such climatic features as excessive moisture, cold summers, long winters. As a result, this region of the Earth is sparsely populated, as severe weather conditions impede the normal functioning of infrastructure and human life. The exceptions are Murmansk, Arkhangelsk and a number of other major Northern ports of great strategic importance.

In general, the settlements located in the Arctic zone are small in number and often have a specialized character. The mass population of the Arctic by people is prevented by the duration and severity of winter, excessive moisture, almost complete absence of conditions for agricultural work, limited flora and fauna.

In turn, the Arctic is a unique territory by its climate, the nature, minerals. The Arctic zone represents the shortest way between the most important points of the Globe as North America, Southeast Asia and Europe.

Recently scientists observe the climate changes which is connected with processes of global warming. As a result of these changes the Arctic zone is influenced by the most serious transformations as it is one of the most large-scale places of glaciers concentration. Process of global warming can become the basis for bigger availability of the Arctic. This circumstance attracts sustained global interest to this region [4.7]. fact that there massive deposits of mineral resources are concentrated. Unlike others, more available regions of Earth, reserves of minerals in Arctic are still huge. It is obvious that the main reason of it is inaccessibility of these resources for most people.

The Arctic influences climate and state of environment around the world. This influence is connected, first of all, with processes of glaciers thawing, forming of atmospheric fronts, etc. Even geographical zones, extremely remote from the Arctic region, are influenced by its activity. Global sea level also is in direct interrelation with the processes happening in the Arctic.

Natural and biological capacity of the Arctic region is complemented with strategic aspects.

The Arctic Ocean shelf availability with deposits of mineral resources causes increased interest of the international community to this region. At the same time not only the traditional Arctic states, but other countries begin to show interest in development of the minerals concentrated in the Arctic and take legal steps for penetration into this geographical zone.

Now the international community is interested in development fuel and energy, forest and mineral raw material resources of the Arctic region.

Hydrocarbon raw materials in the general massif of natural resources of the Arctic are on special place. The Arctic oil fields are estimated by the American experts at 90 billion barrels, gas condensate - about 44 billion barrels, gas - about 47.3 trillion $\mathrm{m}^{3}$. Presumably, the reserves of hydrocarbon raw materials concentrated in the Arctic region make about $25 \%$ of undeveloped world reserves of hydrocarbons.

The Northern Sea Route which is a subject of this research acts as one of the most important points of global transport

Nowadays, despite a certain well-known degree of a subject in world practice there is no uniform organizational and legal approach to regulation of the international relations and interests in the Arctic.

The international regime of security in the Arctic zone is insufficiently developed. In addition to the official Arctic states the hyperactivity is noted by the international organizations (the European Union, NATO), the extraregional states and public associations.

In modern conditions concerning the Arctic zone there are several lines contradicting with each other. First "circle" of cooperation, but also certain opposition is introduced by the traditional Arctic states. These countries have a priority for development of minerals, implementation of scientific and technology studying of the nature and economic capacity of the Arctic.

Last years the situation connected with the navigation regime in the Arctic zone and the status of the Northern Sea Route significantly is complicated by the general aggravation of an international situation. The report "The tension in the infrastructure. 
field of the Arctic security caused by climate" is noted that the Russian part of the Arctic zone, presumably will be influenced by the increased impact of climate change towards warming. It means that cleaning of the Arctic of a glacial covering will happen on the Russian territory earlier, than on its American part. Thus, as it is noted in the report, the Russian Federation will get certain advantages in the Arctic region. For the Russian side it will have positive influence on strategic, trade and commercial aspect [11,12,13].

In connection with such provision a number of the states and political forces make demands to change an organizational legal regime of the Arctic, reasoning the importance of this region in global sense. Giving inability of the certain state to dispose "the resources are general for all mankind" as an explanation of the position, the given political strength defends the principle of the Arctic supranational management.

Development of similar trends in worldwide policy led so far to forming of the concept "internationalizations of the Arctic".

The similar point of view on the status of the Arctic zone purchases considerable number of supporters abroad. So, in particular, partly similar approach is divided also by the USA.

It is obvious that each state which is putting forward the concept of "internationalization of the Arctic" in many respects seeks for strengthening in this region of own national positions and to expansion of the influence.

The Northern Sea Route acts as one of the most important nodal points of global transport infrastructure. In the general economic system of Far North the Northern Sea Route is key point of communication between the Far East and the Central Russia.

Russia as the Arctic state is interested in strengthening of own positions in the Arctic region. It is obviously possible to solve these problems successfully only on the basis of full use of NSR.

The value of the Northern Sea Route is also that it integrates different types of transport (pipeline, air, sea, overland). All great rivers of Siberia are connected by the Northern Sea Route in a uniform transportation network.

Now on the map of the Russian Federation there are regions which life support directly depends on NSR. It is, in particular, about a number of the settlements of Taimyr, Chukotka, etc. The Northern Sea Route performs the major functions on providing with all necessary resources the Siberian and Far East military bases, industrial enterprises, aviation and seaports, settlements.

Except listed above, the raising role of the Northern Sea Route at the present stage of its development needs transportation of the extracted mineral, fuel and energy resources. Now it is required to export the huge volume of the mineral raw materials extracted in these areas from the Arctic zone. Development of the gas and oil reserves found in the Russian North assumes need of transportation of these resources by sea that is the most profitable modern method of transportation.
Creation of the organization of interstate level can become one of the most perspective vectors of modern development of the Northern Sea Route and the Arctic region in general. Functions of similar company have to become increasing of transport infrastructure efficiency of the Arctic region and development of the international transport corridor on mutually advantageous conditions.

However, despite understanding at the national level, progressiveness and prospects of similar actions, there are difficulties for the realization. It is, first of all, insufficient development of infrastructure of east part of the Northern Sea Route. Further, the increased competition level from the southern routes become an obstacle for implementation of the stated above plans. The Arctic navigation in comparison with them is considerable more costly as it is required icebreaker assistance and it is followed by influence of adverse climatic conditions, etc.

The Northern Sea Route is characterized by the increased importance for modern Russia. The interest of the whole world in the Northern Sea Route is connected with the fact that it provides development of resources of the Arctic region including fuel and energy, performing highly profitable transit transportations, etc. [3.5].

\section{DISCUSSION}

Thus, the content of natural-science disciplines promotes consolidation of scientific knowledge in some complete scientific world outlook system by determination of intersubject communications which, in turn, provide integrity understanding of development regularities of the world around. So the ability to apply cognitive element economical and geographical competences promotes forming knowledge of regional components. Now in educational institutions economical and geographical education is not fully used by its educational potential. In this regard, graduates of schools are not ready for fast adaptation, are not capable to make decisions independently and use their knowledge actively and creatively. It is necessary to implement fascinating presentation of data in the form of research and project works for geography lessons and at the same time to create conditions for self-development and adaptation of younger generation to the changing social and economic conditions of society activity [9].

Also it is important to diversify work of the class teacher with parents. Special thematic stand can be made for the regular parents' meeting which will help to find the general common ground of family and school for the solution of problems of forming of economical and geographical competence of seniors [8.10].

\section{RESUlts}

Also, it is very important to form economical and geographical competence of seniors in the family. Level of formation of economical and geographical competence of family is caused by degree of economical and geographical education of parents and the level of their economical and geographical thinking. In many educational institutions there 
[6] Hayaleeva A.D. Gaysin R.I., Gaixing I.T. Development of geological and geographical education at the Kazan pedagogical university. Modern problems of science and education. 2019, 2, pp. 32.

economical and geographical education are issued.

\section{CONCLUSIONS}

The received results allow to speak about efficiency of the developed technique of forming of economical and geographical competence of a modern education system.

\section{References}

[1] Gaising I.T., Gaising R.I., Sharipov R.S., Guseynov D.M. Pedagogical technologies in ecology-geographical education of school students. Scientific developments: Eurasian region: materials of the International scientific conference of theoretical and applied developments. Moscow: Infiniti publishing house. 2019, pp. 110-113.

[2] Rudinsky I.D., Davydov N.A., Petrov S.V. Competence. Competencebased approach. M: Hotline, Telecom. 2018, 240.

[3] Sergeyev M., Sokolova N.L., Samokhin I.G. The concept of stimulation of life-long education in the sphere of economy: basic principles. Kazan pedagogical magazine. 2018, 4, pp. 12-20

[4] Starshinova T.A., Mukhametzyanova A.G. Forming of the professional competence on the basis of integrative approach: creation of crossdisciplinary educational and methodical complexes. Kazan pedagogical magazine. 2018, 4, pp. 90-95

[5] Liu, N. China's Emerging Arctic Policy. 2016. URL: https://thediplomat.com/2016/12/chinas-emerging-arctic-policy/.

[7] Charikova I.N., Zhadanov V.I., Charikova V.V., Popov I.A. Methodological aspects of teaching special course "design of construction objects in the Arctic conditions". Modern problems of science and education. 2018, 4.

[8] Rastvortseva S.N. Economic activity in Russian regions. Economic and Social Changes: Facts, Trends, Forecast. 2018, vol. 11, 1, pp. 84-99. DOI: $10.15838 / \mathrm{esc} / 2018.1 .55 .6$

[9] Ignatova I.V., Ignatov E.S. Development of entrepreneurship in the region: drivers and problems. Economic and Social Changes: Facts, Trends, Forecast. 2017, vol. 10, 5, pp. 143-157. DOI: 10.15838/esc/2017.5.53.10

[10] Vasiljev A.G. Russian journal of ecology. Evolutionary ecology in the 21st century: Institute of Plant and Animal Ecology, Ural Branch, Russian Academy of Sciences Yekaterinburg. 2019, pp 102-114. DOI: 10.1134/S1067413619020103

[11] Rocheva O. A. Bulletin of Kazan technological University. 2012, vol. 15, 10, pp. 322-328.

[12] Alexsandr S. Kuznetsov. Russian Professor's meeting. Russian Journal of Physical Education and Sport. 2019, 14(1), pp. 17-22. DOI: 10.14526/2070-4798-2019-14-1-18-24

[13] Morozova I. G. RUSSIAN ECONOMY in THE current CRISIS: PROBLEMS and WAYS out collection of materials of scientific and practical conference of students, undergraduates, graduate students, teachers and researchers: the 20th anniversary of the higher school of Economics KNITU dedicated. 2016, pp. 99-100. 